\title{
The Failure of the International Trade Organization (ITO): A Policy Entrepreneurship Perspective
}

\author{
Ivan D. Trofimov \\ Department of Economics, Macquarie University \\ NSW 2109, Australia \\ Tel: 6-143-767-9827Ｅ-mail: ivan.trofimov1@gmail.com
}

$\begin{array}{ll}\text { Received: September 4, } 2011 & \text { Accepted: September 13, } 2011 \quad \text { Published: March 1, } 2012 \\ \text { doi:10.5539/jpl.v5n1p56 } & \text { URL: http://dx.doi.org/10.5539/jpl.v5n1p56 }\end{array}$

\begin{abstract}
The paper aims to look at the developments that led to the demise of the ITO initiative in the years immediately after World War II. At the heart of the paper is the critical appraisal of the ITO episode from the policy entrepreneurship perspective. We identify six policy entrepreneurship functions that are necessary for the creation of the effective international economic governance structure and liberal international trade regime, and that have to tackle the issues of ideational consensus building, management of policy negotiations (by means of leadership and coordination), construction of appropriate and suitable negotiation proposals, attainment of ongoing political support of initiatives, and making policy formulation process commensurate with a broader economic and political context. It is shown that the failure of the ITO is attributed to inadequate exercise of policy entrepreneurship.
\end{abstract}

Keywords: International Trade Organization, Policy entrepreneurship

\section{Introduction}

The passage of the Smoot-Hawley Act in the USA (1930) is usually considered the event of crucial significance for the international economic order in the pre-World War II period and as the start of a tide of protectionism on a global scale (Sennholz, 1988). With the average tariff rate increased to 59\% (the highest since 1830) for almost 12000 tariff lines, it led to a chain of retaliatory actions and "beggar-thy-neighbour" policies on the part of US trade partners, thereby causing disruption in international trade and markets, deepening Great Depression and prolonging recovery from it, as well as undermining international cooperation at the time when it was most needed (in light of threatening political developments in Europe).

The subsequent efforts of the US government in the 1930s-1940s (in particular of the F. D. Roosevelt administration) were to prevent the repetition of this course of affairs. ITO negotiations in this respect were part of the "grand" post-war negotiations over a future non-contentious international economic and political order (Gardner, 1980) (Note 1). The policymakers of the 1940s envisaged the creation of a comprehensive institutional structure that would deal with international economic governance and cooperation. This structure was designed to include four bodies the UN, IMF, IBRD (World Bank) and ITO. The UN was intended to be political structure to ensure the peaceful coexistence of nations, the IMF was created to provide a stable monetary regime based on the US dollar as the reserve currency, the IBRD was set up to facilitate post-war recovery and to otherwise assist economic development, whereas the ITO was envisaged to regulate international trade affairs. As shown below, this grand political undertaking was successful in all pillars except the last one.

The failure to establish liberal trade order under the organizational umbrella of the ITO is not merely an antiquarian historical fact, but rather a critical juncture that has implications for contemporary policymaking and a case that necessitates theoretical explanation. As attested by the difficulties in constructing free trade order in the GATT/WTO system that have been experienced over a sixty year period following the ITO demise and also by the persistent failures in multilateral policymaking in other areas (e.g. climate change, international monetary affairs), the analysis of the ITO episode may provide answers as to what is required for building effective international governance.

The purpose of this paper is therefore twofold: 
1) To provide an adequate explanation of the ITO fiasco; and

2) To elaborate theoretical constructs for the analysis of multilateral policymaking.

Specifically, we look at the agricultural trade policy aspect of the ITO undertaking, due to the special role that agricultural regulation and food provisioning played in the 1940s (the importance of foodstuffs for post-war reconstruction; the need to stabilize international agricultural markets through commodity agreements and avoid the repetition of agricultural depression of the 1920s; to coordinate food surplus disposal that stemmed from the newly erected national farm policies; to ensure market access for food producers etc), and also because of agricultural "exemptionalism" that followed the demise of the ITO and had been persisting in the GATT/WTO system ever since (Josling et al, 1996).

The existing studies examine two aspects of the ITO failure. Firstly, the complexities of the ITO ratification process are emphasised. As put by Milner (1997: 139-141), due to the prominent role of the USA in the international system of the time, it was expected that ratifications by other signatories would start after the ratification by the US Congress of the ITO Charter. This did not happen because of the protectionist and isolationist position of the Republican Party that took over the Congress in 1947 and the opposition of the organized interests (unions, peak farm associations), and therefore the adoption of the ITO Charter stalled. Secondly, the public opinion and communication problems in the US trade policy domain are underscored (Aaronson, 1996): the American citizens were apathetic about ITO initiative and saw no link between ITO adoption and the potential to increase living standards, whereas the US trade policymakers did little to educate the American public about the issue. The result was a gradual disappearance of the ITO initiative from the US political agenda of the late 1940s.

Not rejecting these interpretations we align with the view of T. Zeiler (1992: 9, 13-17) that the success of the liberal trade policy initiatives hinges upon strategic action and leadership of top policymakers and bureaucrats, and to lesser extend upon the organized interests and diffused public opinion. We outline six policy entrepreneurship functions (framing, construction, leadership, coordination, consensus-building, and contextualization) that have to be exercised to ensure the adoption of a trade policy, and examine how these functions were performed in the ITO case.

\section{Framing}

The function of entrepreneurial framing is to mould the "primeval soup" of ideas, views and blueprints spread across the policy system into an articulated argument (containing in itself the diagnosis of the policy problem as well as tentative solutions) that would be accepted by a sufficient number of policy actors and that would direct and guide policymaking (Schon, Rein, 1994).

As policy system is pervaded by opposing ideas and frames, the attainment of a shared frame is not an unconflictual process, with actors attempting to push forward and impose their desired frame. While the form of framing will vary substantially depending on the policy setting and the degree of dissonance between existing and alternative frames, the essence of framing is a normative de-legitimisation of existing policy ideology and presentation of the latter as inappropriate in the eyes of society and unsuitable for solution of policy problems. The mechanics of framing is based on rhetorical actions and appeals to "follow the right way" and desist from currently held frames (Note 2). Following Benford and Snow (2000) we argue that the success of framing rests on the resonance of the argument, determined by its consistency (clear cut interpretation of what is wrong and why it has to be tackled in a particular way) and credibility (frames not contradicting reality and not advanced solely for demagogical and politicking purposes).

Two competing frames, related to international economic problems, were available in the early post-war years.

The frame carried by the US Department of State (DoS) and in particular by its head - Secretary of State Cordell Hull (1871-1955) was, in nutshell, as follows (Note 3). The trouble of the 1930s and the prolonged Great Depression and international economic conflicts that paved the road to World War, was considered to have resulted from 
externalisation of domestic economic problems and manifested in proliferation of non-tariff trade barriers and competitive devaluations, enacted to correct the balance of payments, as well as in the rise of regional protectionism, as well as from private responses (international cartels) to lift prices. Consequently, the solution, presupposed by this diagnosis, was straightforward - to dismantle protectionist machinery (particularly import quotas, exchange controls and systems of preferences), to put a brake on manipulations with exchange rates, delegating control over balances of payments correction to the IMF, and to restrain public and private monopolistic and market control practices.

The other frame that had already been established and was considered legitimate (both in many segments of the US policy system and overseas) by the time the DoS lodged its proposals was that the tragedy of the 1930s was not caused by trade rivalry and inadequate international policy responses, but by the lack of government intervention. The practical implication of this diagnostic frame was that achievement of full employment, and the rise of productivity and growth through aggregate demand stimulation should precede trade liberalization, an idea in stark contrast with the Department of State solution (Capling, 2001: 14).

Specifically in the agricultural sector the consensually held interpretation of the 1930s events on both sides of Atlantic and in Australia was that two intertwined factors were behind the poverty of the farm sector - the lack of measures to control overproduction and the absence of an agricultural welfare state and social guarantees (the latter leading to the destitution depicted by J. Steinbeck in The Grapes of Wrath and by popular press). Trade protectionism exacerbated this state of affairs. However, if free trade resumed, it would have had welfare effects similar to protectionism, leading to worldwide agricultural overproduction. Consequently the credo of farm circles was as contained in a USDA pamphlet: "Relaxation of trade barriers could not remedy a serious world surplus situation, nor could it prevent widespread agricultural depression.”(US Government, 1945)

In light of the above, the framing attempts by the DoS were doomed for both lack of consistency and credibility. Regarding former, the arguments of Cordell Hull misinterpreted the link between economic activities and outcomes, mistakenly implying that the dismal state of post-war economies was predominantly due to disruption of the international market, whereas the real problem was the difficulty of reconstruction and reconversion. The solution proposed was unrealistic because it disregarded these exigencies of the time and also because it was at odds with policy path dependencies and economic development priorities that existed elsewhere in the world and with the nascent economic policy philosophies (i.e. Hull did not convince international delegates why problems had to be tackled in his way). Out of all participants in ITO conferences only Canada (due to its integration with US economy and willingness to abandon preferential links with the UK) could probably agree with Hull's original diagnosis and solution (Pomfret, 2000). The UK, despite its high dependence on US credits and hence limited freedom of manoeuvre, in domestic policy subscribed to Keynesianism (and was not content with US imports and foreign investment undermining domestic economic recovery programs). It was also unwilling to abandon existing foreign trade policies (Imperial Preferences), which were instrumental in the preservation of the colonial system and established relations with dominions. France likewise was concerned about its preferential system; in addition it traditionally stuck to state dirigisme as a means of curing economic problems. The block of agricultural and developing economies, led by Australia, prioritised economic (particularly industrial) development through import substitution and similar measures (Capling, 2001: 23). Centrally planned economies (with the exception of Czechoslovakia) outright denounced the ITO undertaking. Thus, as Heilperin put it in 1950, "the kind of ITO that the United States might properly join would find in the world of today very few adherents."

Regarding credibility of DoS frames, the arguments of Hull were considered utopian and idealistic and therefore out of place. It was clear to targets of Hull's counter-framing that pre-World War I unrestricted free trade times (no matter how good they were) had long passed. In addition the frame contradicted actual US policies - it was obvious 
that the US Government was not planning to refrain from its agricultural support policies, instituted during the New Deal, nor could it ignore the necessity of massive state involvement during the process of reconversion to peace production (the exemptions for the shipbuilding industry, raised by the USA during talks, are indicative in this sense). Finally despite the rhetoric of multilateralism and international economic neighbourliness, it was obvious to many in the 1940s that the underlying rationale of US efforts was maximisation of national power, for which "free trade imperialism" (export expansion and export of US capital) was an instrument. A reading of US Government statements of the time reveals that concerns of US businesses (especially fear of a new depression) were at the forefront of US external economic policy (US Government, 1948). This expansionism was evident in lend-lease agreements and reached its apex in the Marshall Plan. Consequently, the integrity and credibility of US counter-framing were undermined - if American agriculture and industries were protected, why not infant industries in the developing world or British preferential trade? If the US subsidises its farm exports, why cannot Brazil or any other country erect barriers against it?

In this hostile, anti-liberal environment, it is no wonder that US pro-liberal policy entrepreneurship was compromised from the very beginning. Nonetheless, many opportunities discussed below still existed but had not been exploited fully.

\section{Entrepreneurial Construction}

As put by Schumpeter (1934), the essence of entrepreneurial action is introduction of technical, organizational and product innovations into the economic system by means of recombination (or creation of new combinations) of existing production resources and inputs. Following Sheingate (2003), we argue that such recombinant activities are also encountered in the policy space, where new policy products are constructed from available proposals, submissions and blueprints of parties involved in policymaking (Note 4). The effectiveness of entrepreneurial construction will thus critically depend on the ability of entrepreneurs to remain open to and to make use of other actors' inputs. Also, as put by Schumpeter (1934:90), the crucial psychological features of entrepreneur are creativity and ingenuity when it comes to ends and means of entrepreneurial action, and in particular to finding novel means to achieve desired ends. The policy entrepreneur too is likely to be ingenuous in finding the ways to ensure that proposed policy constructs and frameworks will work in the given political economic and social context and that thereby policy goals will be reached. We posit that entrepreneurial construction during the ITO episode was deficient in terms of these two conditions.

DoS found it necessary to complement the reciprocal trade agreements that had been enacted by the Roosevelt Administration in 1934-1946 to restore international trade with a more encompassing and, most importantly, legally and organisationally stringent, multilateral treaty (the details of which were contained in the November 1945 Proposals by the US Government).

The applicability of both of the two liberalization modes to practical economic policymaking of the 1940s was however questioned. American economists R. Schwenger and L. Wheeler (Henningson, 1987; Schwenger, 1945), argued that DoS took for granted that both multilateral and reciprocal liberalizations would work: the USA in order to expand its exports would reciprocally open its immense market for imports; other economies would replicate this move in their bilateral relations and a worldwide movement to free trade would set in. Wheeler objected to this, stating that while (irrespective of the liberalization mode) relaxation of trade barriers was essential; it had to be accompanied by restoration of purchasing power in war-torn economies so that the latter could pay for US imports. Moreover, restoration being a slow and painful process, it required that US liberalization moves were neither radical nor compromising of domestic recovery programs in these economies. Without this modification no theoretically sound design would be practically implementable. Indeed, the failure to enact this measure would lead to 
unexpected and opposite results: the flooding of international market with US goods and subsequently the surge in protectionism overseas. Thus, we argue that the obsession of the DoS with removal of trade barriers and only limited attention to the cautions of above-mentioned economists decreased the effectiveness of entrepreneurial action by the DoS.

Regarding applicability of DoS designs to the political and organisational context of the time, not only did reciprocal trade agreements signed before war quickly become outdated (with some signatories changing their political regime and others reversing their economic policy, as evidenced by difficulties in negotiating trade agreements with France and the UK after the war), but also the whole idea of putting a world system that was in disarray into a legal/organisational straightjacket was viewed by target states as totally unrealistic. Ex post, several properties of the system may be identified, that could have been accounted for, which in its turn could have made entrepreneurial construction efforts more effective:

1) The unsettled direction and nature of trade flows (stemming from emerging political divisions in Europe, colonial wars, the absence of regulatory authorities in Germany, Austria and Japan etc);

2) The differential pace of reconstruction (resulting from non-uniform war-time distortions and manifested in different inflation rates, dependence on raw materials and export capacity); and

3) The different mix of recovery instruments (direct state administration, maintenance of private cartels, exchange controls, export subsidisation and import substitution, relocation of industries etc).

In this respect, as rightly noted by Dam (1970), the appropriate form and method for bringing in correct normative economic principles (abolition of quantitative restrictions, restriction of export subsidisation) and, importantly, extending them to sensitive areas (agricultural trade) would have been the creation of a forum, where countries could settle their international economic issues on a bilateral basis and in a flexible manner, that suited both sides (instead of convoking countries with diverse objectives and capacities of conducting trade). Codification, as an attempt to set fixed rules, comprehensiveness, as an attempt to tackle all trade restrictions existing at the time, not to mention the sternness and inadequacy of the preparatory process and legal and organisational framework (unanimity as a procedure of ITO adoption as well as excessively stringent ITO rules enforcement process in the International Court of Justice), were therefore a serious flaw in the ITO blueprint of DoS (Note 5).

Another failure of the entrepreneurial construction was attributed to the inability or unwillingness of the DoS to make use regulatory inputs by the agricultural policy actors, specifically the US Department of Agriculture (USDA) and farming community. As a result, no appropriate framework for regulating international agricultural affairs was devised.

The above mentioned April 1945 Proposals on agricultural trade expansion contained suitable designs to deal with the problem of agricultural surpluses. The USDA proposed to devise international commodity agreements (ICAs). In contrast to cartel-type agreements practised during war for selected commodities (rubber, sugar, tea) and used solely to restrict production, USDA blueprints envisaged agreements that would have both stabilised prices and boosted consumption. It was suggested that minimum and maximum prices should be set with managers of ICAs purchasing excess stocks to protect sellers when prices fell to the minimum and selling excess stocks to protect buyers when prices reached the maximum. Excess stocks would be disposed of to underdeveloped areas and this process would be put under international control. This last measure would have prevented an uncontrolled dumping of the food surpluses by individual countries that became a usual practice in the post-war period (frequently aided and masked by the food aid programs (e.g. "Food for Peace" program in the USA). While details of the ICA proposal had yet to be elaborated (in particular the issue of how ICAs would account for complexity and diversification of farm economies, and how purchases/sales of buffer stocks had to be financed), the USDA idea seemed workable and was considered positively in farm circles both domestically and internationally, as evidenced by the approval of the 
proposal by the newly formed International Federation of Agricultural Producers and constructive discussion of the proposal in farm journals (Davis, 1947; Hopkins, 1947).

Importantly, the ICA proposal well acknowledged the problems of the uncritical application of free trade ideas to the regulation of international agricultural affairs. Schwenger and Wheeler, who were the authors of the proposal and the participants to the war-time ICAs negotiations, debated that free trade advocated by the DoS could only bring benefits if the farmer was able to adjust rapidly enough to changed international market conditions (e.g. by adjusting its production process and structure to changed international prices), which may not have always been the case. In contrast, domestic farm regulations instituted in the 1930s in the USA and Europe had the opposite objective - to bring in stability and orderly conditions to the farm sectors, in particular by insulating them from the international markets through protectionist trade barriers. Hence, there was an obvious incompatibility between free trade and domestic policy. In light of these domestic policy constraints, an attempt to establish orderly conditions in international agricultural markets and foster international economic cooperation through free trade was seen as futile, whereas the only viable option was a coordination and fit of domestic farm programs through ICAs (allowing both restoration of trade flows and more or less normal operation of international markets and continuation of domestic farm programs).

This valuable input that was based on sound economic prescriptions and which was in all respects a far better operationalisation of international agricultural issues than the DoS proposals was not accepted favourably by US negotiators. DoS firstly blocked the initiative of the USDA to discuss ICAs separately in the newly established Food and Agriculture Organization (FAO), the forum of likeminded and sympathetic agricultural professionals, thereby depriving FAO of any say in international economic matters and confining it to economic research and statistical functions (United Nations, 1946). Secondly, DoS hampered inclusion of the ICA provisions into the US proposal for ITO, expressing doubts about the compatibility of the idea with DoS visions of universal free trade. It did not support ICAs, either in domestic negotiations with USDA or in the course of ITO conferences - in the latter case DoS continued to insist on the temporary nature of ICAs (limiting them to five years). This point was, in the course of ITO negotiations, mutilated at the request of other countries (taking the same pro-ICA stance as the USDA) with an unlimited number of five year renewals allowed (Article 65 of Havana Charter). Nonetheless, due to the doctrinaire position of DoS, actual ICA provisions in the Havana Charter were deemed unworkable and not suitable as a long term sustainable regulatory solution to management of international agricultural markets or to pressing problems of US agriculture (as USDA wanted it). The requirement was imposed that domestic adjustments be undertaken to solve underlying surplus problem. This requirement was unfeasible, as domestic support programs were likely to perpetuate (Article 63-d). It was also stipulated that consuming and producing countries get an equal vote (weighted by volume of exports and imports) during preparation and formulation of an ICA, thereby creating inevitable difficulties in negotiating the ICA (Article 63-b). Finally, actual ICA negotiation was allowed only in rare circumstances of serious distress to producers (Article 62).

Overall, the ironic outcome of DoS blockage of the entrepreneurial initiative of USDA and other governments was that its attempts to prevent the repetitions of destructive trade rivalries of the 1930s resulted in international agricultural policies remaining in the hands of national governments, introducing export subsidisation, food disposal and other programs in a purely uncoordinated and destructive fashion, thereby leading to trade wars. Subsequent GATT realities confirmed the prediction of Schwenger and Wheeler that "unless there are multi-lateral commodity agreements to provide orderly marketing conditions there would be cut-throat wars involving dumping of commodities and competitive subsidizing of exports.” (Henningson, 1987: 89) 


\section{Entrepreneurial Leadership}

The concept of leadership is central to the analysis of entrepreneurship by J. A. Schumpeter (1934). Seeing entrepreneurial leadership as a "dominant mechanism of any collective action" (p. 270), Schumpeter defined leader as a figure who makes qualitative and non-incremental changes to political and policy system (e.g. reorganization of decision-making structures, creation of new forms of government intervention, expansion or minimisation of its scope etc) by means of radical actions - forcing particular decisions and agendas, giving new directions to public debates, persuading the public and opposition about the benefits of new policies, i.e. performing actions that span beyond the mere execution of bureaucratic tasks and routines. These actions help leader to improve his position within the decision making and bureaucratic system (in the case of non-elected policymakers) or establish himself as a political monopolist (the case of elected politician). In addition, Schumpeter stressed the crucial behavioural characteristic that distinguishes leaders from bureaucrats - the former have higher-order objectives not confined to utility-maximization (promotion, re-election, retention of the post) or limited to narrow policy agenda, but rather dictated by their deeper and broader visions of "good" social order.

We argue that two period of entrepreneurial leadership may be distinguished during the ITO episode - "before" and "after" the resignation of the Secretary C. Hull, with no actors willing to act as leaders in the latter period.

The ITO was a brainchild of C. Hull and few of "his" people in DoS, advocating the Wilsonian idea of international cooperation and free trade as an instrument to achieve it, as epitomized in Hull's saying: "Economic peace offers the greatest assurance of permanent world peace. Artificial trade barriers invariably create bitter trade rivalry, vicious trade practices, and economic wars, which in modern times have been the prelude to actual wars." (The New York Times, July 25, 1931). The leadership of Secretary Hull particularly manifested during war time, when the vague idea of economic peace was turned through a series of discussions and seminars within DoS into a comprehensive and detailed proposal, and then elevated to the forefront of the US foreign policy agenda, and when intense advocacy of the proposal within the US Government and Congress took place.

The problem with the ITO negotiations was that by the time the full scale talks started in September 1945, Cordell Hull had already resigned from his post. Hall's successors in the State Department, did not possess his grand visions, share the same foresight, or have the similar leadership qualities (Diebold, 1952).

The problem of pro-free trade leadership was exacerbated by the lack of other figures that could act as entrepreneurs. As opposed to later periods (leadership of GATT Director General and top domestic figures in the Uruguay Round) or other areas (the prominent role of the US Secretary of Treasury H. Morgenthau in the Bretton-Woods Conferences), the international bureaucrats, who could advocate the free trade idea in the multilateral arena, were absent (due to no existing international body). In principle, as the ITO and other economic conferences of the 1940s were conducted under the aegis of the UN, its Secretary General (then Trygve Lie) could act as leader, or at least coordinator and mediator (the latter being part of his function). Due to intensity of political discussions in the UN, he preferred to limit his involvement to ceremonial acts, as evidenced by speeches made by his deputies on his behalf on opening and closures of ITO conferences (United Nations, 1947, 1948). Also, as a result of the above mentioned divisions between the US delegates and FAO, its bureaucracy (particularly its director general J. B. Orr) was reluctant to intervene into ITO affairs (specifically the agricultural pillar of negotiations) after the conflict over ICAs.

As to external actors, none of the prominent economists of the time was willing to set a free trade agenda in ITO conferences and act as an "intellectual" leader. In addition, those economists interested in free trade policy outcomes were at the same time strongly critical of the ITO Charter that was agreed to in the Havana Conference and that was seen as too statist and socialist (Note 6). 
Similarly, no top political figures (e.g. President H. Truman) had any incentives to engage in ITO negotiation on a consistent basis and track its developments. The role of the US President in ITO events points to the principal pitfall of presidential leadership. Too frequently, the top figures overwhelmed with other issues (as was Truman in the 1940s, dealing with the Cold War and containment of communism), assume that decisions made or positions stated will materialise without being mutilated by domestic bureaucrats or in international bargaining process and that no further leadership is required. Such was the case of the ITO: Truman let the US proposal drift in ITO negotiation process, thus giving room to other entrepreneurs to direct the process. The problem was that these entrepreneurs were not sympathetic to DoS proposal: such figures as H. C. Coombs (the Australian delegate and the member of ITO Preparatory Committee) had clear anti-free trade priorities.

\section{Entrepreneurial Coordination, Consensus Building and Contextualization}

Kirzner (1973) considers entrepreneur as a coordinator and facilitator of the market process: by detecting existing price discrepancies in the market (disequilibrium conditions) and corresponding profit opportunities, entrepreneur exploits these opportunities and leads market to an optimal allocation of resources to more highly valued uses, i.e. to equilibrium. We argue that Kirznerian entrepreneur is also present in the policy space.

The principal policy disequilibrium is that actors may lack an agreement on whether and when a policy problem should be attended to and when actual negotiations between parties should start. Hence the task for Kirznerian policy entrepreneur is to facilitate policy process, by steering consensus building process among actors around the policy initiative in question, thereby firmly putting it on the agenda (i.e. consensus building entrepreneurship). In addition, entrepreneur's task is to help actors find the right moment for agenda setting and negotiation, by taking into the surrounding political, social and economic circumstances and developments (contextualization entrepreneurship).

The other policy disequilibrium is associated with unsubstantiated or over-optimistic expectations by actors that their negotiation positions and proposals can fit easily, subsequently leading to "unpleasant" discoveries that full negotiation potential had not been exploited and that negotiations could have progressed in a more speedy fashion (avoiding some actions and making others). The task of Kirznerian entrepreneur is therefore to coordinate negotiation process, by taking relevant strategic actions that would eliminate processual inefficiencies and in the end benefit all parties to negotiation. In this regard Schoppa (1997) mentions among others such strategies as restructuring of constraints (modifying the balance of interests in the opposing country or domestically, by making positive inducements and side payments to recalcitrant stakeholders) and credible threats (sending credible signals to the target country that its existing or potential trade benefits in a specific area will be decreased or annihilated).

We argue that Kirznerian entrepreneurship was not adequately exercised by the DoS, the sole pro-free trade body negotiating on behalf of the USA in the ITO conferences.

At the international table, the necessary economic and political power that the USA possessed at that time would accord it unprecedented ability to "crash" and/or "buy" opposition and coordinate talks in desired way. Instead the US negotiators firstly eagerly subscribed to a UK proposal to introduce a balance of payments escape clause that would sanction the use of import quotas (Article 4 of Havana Charter). The failure to preclude this development, which was detrimental to the US exports (including agricultural ones), effectively angered US domestic stakeholders and prevented formation of a potential pro-ITO coalition (The New York Times, June 25, 1947, p. 15). Secondly, the USA did not manage to forestall developing countries from legalising import restrictions to promote economic development. Despite the initial proposal by the USA to assist this task through direct production subsidies instead of trade barriers (US Government, 1946), the protectionist provision prevailed (on the insistence of Cuba and India) in the Havana Charter. Thirdly, the US delegation did not avert the introduction of provisions on the assistance to 
and financing of economic development and reconstruction (Articles 10 and 11). This point was particularly far-reaching as it envisaged international administration of the capital and other resources (coming predominantly from the USA at that time) accorded for the above purpose, yet without explicit guarantees to US foreign investment (Article 12-1a).

All in all, the intended US liberal draft became gradually eroded and cluttered with contradictions and dispensations, eventually turning into a protectionist document (unratifiable in the USA). One of the contradictions was the presence of both full employment provisions and legitimate import restrictions that follow from balance of payments difficulties. It was not recognized that the latter are the result of the former: the stimulation of aggregate demand leads to higher imports and trade deficits and thereby to protectionist pressures. It was also left unclear how to resolve the conflict between the pursuit of full employment and economic development policies and the need to avoid quantitative trade restrictions. If the latter took precedence, as was proposed by some delegates, this would have virtually negated any free trade meaning of the ITO (Heilperin, 1948: 4).

Undoubtedly, US delegation obtained some concessions (on downsizing preferential tariff systems) and obviated certain radical developments (inclusion of binding provisions on policies promoting full employment). Nonetheless, it was very rare that US negotiators were able to manage ITO talks and direct delegates' attention to the discussion of trade liberalization and to arrest their interventionist and protectionist "zeal". One of these rare occasions was the statement of Clair Wilcox on December 23, 1947, when he warned that delegates were too easily assuming that the US public and business would accept the amendments introduced and that USA would not introduce similar regulations to protect its national economic interest. His voice was not heard however (Heilperin, 1949: 81).

Regarding the pro-ITO consensus building abroad (e.g. in Western Europe) it was unlikely that pure reverberation about the benefits (including long-term ones) of a "liberal ITO" would have worked, due to entrenched anti-free trade frames and unrealism of the DoS proposal (see Section 2). However, in terms of strategic actions it was still possible to gain support (e.g. through such positive inducements as provision of concessional credit facilities and other measures to launch trade, as well as selective removal of trade barriers in the USA) from businesses and export sectors in the countries that benefited from export orientation and open markets before the war (Netherlands, Belgium, Denmark). No measures were taken by the DoS and consequently these potential allies got isolated and silenced in the policymaking systems in these countries (particularly in light of dire economic situation of 1947-1948 and strong pressures from other actors to concentrate on more urgent matters of economic reconstruction). Likewise, the possibility of making credible threats (including such harsh measures as making food aid and support of politicians in the target countries conditional on compliance in ITO negotiations) was not fully exploited by the DoS.

Domestically in the USA the opportunities for the pro-ITO and pro-free trade consensus building and strategic action by the DoS were available, but were not adequately exploited. American business interests were divided in their attitude towards free trade and as to the desirability of the ITO ratification (Bidwell, Diebold, 1949; US Congress, 1950). The interests seeking protection and opposing the whole DoS free trade initiative were concentrated in the National Association of Manufacturers, representing the industries directly competing with European producers. Other business associations, while paying lip service to free trade idea and free markets philosophy, were in fact holding anti-competitive objective of international expansion supported by the dominance, monopoly power and consequently competitive position in certain sectors (banking, insurance, shipping, technology-intensive manufacturing). Their concern was the presence of competition regulations and anti-cartel policies in Havana Charter that could have hampered such business expansion plans as opening of foreign branches by the US banks and that allegedly did not take into account the unique position of the American business after war 
(that was not particularly due to its monopolistic practices, but rather to the absence and weakness of competitors in the worn-torn Europe). Without clarification of the content and implications of these Havana Charter provisions by the DoS National Planning Association, The Committee for Economic Development and National Foreign Trade Council, representing export and finance sectors, aligned with the National Association of Manufacturers and ruined ITO ratification. In this regard, pro-active position of the DoS, informing domestic stakeholders of the real nature of the ITO (Note 7) could serve both consensus building and strategic (restructuring domestic constraints and destroying anti-free trade coalition) functions.

As to US agricultural interests, their outrage at the ITO in late 1947 was not inevitable. The farm sector was initially satisfied with the original US proposal retaining import restrictions, protecting US farmers from foreign competition and keeping US agricultural legislation intact. The adherence of other countries to import restrictions was, however, a concern for US agricultural exporters, who, at the end of the 1940s, had a clear comparative advantage in a number of products, and therefore expected benefits from export expansion. ITO market access provisions (import quotas) provided little promise. With the inevitability of import quotas in the ITO, the DoS successfully tried other avenues, namely managed to have the use of export subsidies of primary products legitimised in the Havana Charter, thereby satisfying US agricultural export interests. Nonetheless, shortcomings in consensus-building by the DoS were present. Firstly, it did not attend to the legitimate concern of US farmers, who feared that their interests may get lost in an ITO "machine" and that therefore tighter collaboration between the ITO and farmers was required. Indeed the International Federation of Agricultural Producers was seen as a grassroots complement to regulate international agricultural affairs (Davis, 1947). Secondly, the DoS did not clarify that the tariff reductions in the GATT Geneva Round (taking place concurrently with ITO preparation) were not a prerequisite for ITO adoption or a requirement imposed upon the USA in respect of ITO, or that they compromised existing agricultural support policies. As a result, the fears of potential losses to the farm sector set in, being the ultimate reason of the rejection of Havana Charter by the US farm sector.

Finally, it may be argued that pro-ITO actors did not select the right time for negotiations. We posit that the timing most conducive for discussing the issue is when all potential participants face deterioration of their economic fortunes and have no other means to avoid trouble (i.e. when they face integrative, acute and general crisis). While in the USA in 1946 the fear of a coming new depression (associated with the termination of military programs of the government) was on the rise, it was not a strong incentive for US stakeholders to rush into the ITO project. The economic difficulties of the early post-war years were believed to be transitory and the long-term economic prospects promising (as indeed proved to be true). Overall, in 1946-1948 the economic situation was not perceived as a crisis of any substantial proportions. Similarly, while in Western Europe the deterioration of economic conditions was obvious, the policymakers there contended that they could find a way out of trouble without the ITO negotiation (e.g. through bilateral credit and food aid agreements with the USA, reliance on trade with colonies to help and creation of preferential trade zones, and above all through emergency measures administered by the state). Overall, multilateral joint action was not considered necessary. The timing for joint action could have come in 1950 with the start of the Korean War and the feeling of joint vulnerability to Communist threat. By then, however, the ITO project was already abandoned by all parties. Alternatively, it might have been possible to capitalise on the enthusiasm associated with the 1945 victory and formation of the UN and Bretton Woods institutions - the ITO could come as attachment. In other words, the ITO should have been negotiated no later than 1945 or after 1950. DoS, which to large extent planned and prepared ITO conferences, had to be alert to propitious external circumstances - the inability to do so was a manifestation of Kirznerian entrepreneurship failure.

\section{Conclusion}


The above discussion revealed that the failure of the multilateral free trade proposals and of undertakings aiming to establish international economic organizations is a multifactorial phenomenon, best explained through the prism of deficient entrepreneurial action performed by top government actors. Six complementary entrepreneurial activities have been identified each of them essential for creation of the stable and working international governance structures. The attainment of the consensually held frame (i.e. the shared interpretation of what the problem is and what should be done to solve it) is required for setting the ideational background propitious for a specific policy initiative - without it any further attempts to build consensus or strategic actions to direct policy talks towards specific outcome may prove futile. The construction of policy proposals that takes into consideration their appropriateness and suitability and that incorporates the inputs from all interested stakeholders determines the sound content of the policy. Entrepreneurial leadership is seen indispensable in ensuring that the momentum of negotiations is kept, and importantly that the policy initiative is not eroded or narrowed down and that broader reformist ideas and proposals always remain on agenda and on negotiation table. Consensus-building aimed at ensuring ongoing support of the policy initiative at the national level, and strategic actions, targeting the removal of constraints within national political systems or at international talks are seen as activities allowing smooth and swift progression of the policy talks (i.e. playing coordination and facilitation roles). Finally, contextualisation activities are considered important for selecting the right moment and timing for the agenda setting and negotiation.

We posit that while the specific configuration of these six entrepreneurial functions, their strength and importance will undoubtedly vary depending on the multilateral policy and issues in question, all six functions will inevitably have to be exercised. Further case study and historical research, outlining the role of agential and entrepreneurial factors in the international governance (economic and non-economic) fiascos is necessary.

\section{References}

Aaronson, S. (1996). Trade and the American dream: a social history of postwar trade policy. Lexington: University Press of Kentucky.

Benford, R. D., \& Snow, D. A. (2000). Framing processes and social movements: an overview and assessment. American Journal of Sociology, 26, pp. 611-633.

Bidwell, P. W., \& Diebold, W. (1949). The United States and the International Trade Organization. International Conciliation, 27, pp. 187-239.

Capling, A. M. (2001). Australia and the global trade system: from Havana to Seattle. Melbourne: Cambridge University Press. http://dx.doi.org/10.1017/CBO9781139106887

Cortney, P. (1949). The economic Munich: the I.T.O. Charter, inflation or liberty, the 1929 lesson. New York: Philosophical Library.

Dam, K. W. (1970). The GATT: law and international economic organization. Chicago: The University of Chicago Press.

Davis, J. H. (1947). The International Federation of Agricultural Producers. Journal of Farm Economics, 29 (4), pp. 1101-1106. http://dx.doi.org/10.2307/1232739.

Diebold, W. (1952). The end of the ITO. Princeton Department of Economics Working Paper No. 16. Princeton: New Jersey.

Gardner, R. N. (1980). Sterling-dollar diplomacy in current perspective: the origins and the prospects of our international economic order. New York: Columbia University Press.

Garrett ,G. (1947). More about the world trade charter. American Affairs, IX (2), pp. 75-83.

Heilperin, M. A. (1948). Notes on the Havana trade charter, Canadian Banker, May.

Heilperin, M. A. (1949). How the US lost the ITO Conferences. Fortune.

Heilperin, M. A. (1950). Elephant traps in the ITO. American Affairs, XII (3).

Henningson, B. E. Jr. (1987). The wealth of nations and the poverty of producers: the conflict between free trade and the New Deal farm program. Agricultural History, 61 (1), pp. 74-93. 
Hopkins, J. A. (1947). Significance of the Geneva trade conference to United States agriculture. Journal of Farm Economics, 29 (4), pp. 1055-1071. http://dx.doi.org/10.2307/1232735

Josling, T., Tangermann, S., \& Warley, T. (1996). Agriculture in the GATT. Basingstoke: Macmillan. http://dx.doi.org/10.1057/9780230378902

Kirzner, I. M. (1973). Competition and entrepreneurship. Chicago: The University of Chicago Press.

Milner, H. (1997). Interests, institutions, and information: domestic politics and international relations. Princeton; Princeton University Press.

Pomfret, R. (2000). Trade policy in Canada and Australia in the twentieth century. Australian Economic History Review, 40 (2), pp. 114-126. http://dx.doi.org/10.1111/1467-8446.00061

Schon, D., \& Rein, M. (1994). Frame reflection: toward the resolution of intractable policy controversies. New York: Basic Books.

Schoppa, L. J. (1997). Bargaining with Japan: what American pressure can or cannot do. New York: Columbia University Press.

Schumpeter, J. A. (1934). The theory of economic development: an inquiry into profits, capital, credit, interest, and the business cycle. Cambridge: Harvard University Press.

Schumpeter, J. A. (1939). Business cycles: a theoretical, historical and statistical analysis of the capitalist process. New York: McGraw-Hill.

Schwenger, R. B. (1945). World agricultural policies and the expansion of trade. Journal of Farm Economics 1945, 27 (1), pp. 67-87. http://dx.doi.org/10.2307/1232263

Sennholz, H. F. (1988). The Great Depression: will we repeat it? Spring Mills: Libertarian Press.

Sheingate, A. D. (2003). Political entrepreneurship, institutional change, and American political development. Studies in American Political Development, 17, pp. 185-203. http://dx.doi.org/10.1017/S0898588X03000129

United Nations. (1946). Proceedings of the First Session of the Conference. Washington: FAO.

United Nations. (1947). "Second Session of the Preparatory Committee of the United Nations Conference on Trade and Employment. Non-Governmental Organizations." Geneva.

United Nations Conference on Trade and Employment. (1947). Press release ITO/1, 21 November 1947; Press release ITO/224, 24 March 1948. Havana, Cuba: Department of Public Information. (Statements of T. Lie, read by D. Owen and B. Cohen).

United Nations Conference on Trade and Employment. (1948). Final Act and related documents. Lake Success.

United States Congress. (1950). "Membership and participation by the United States in the International Trade Organization." Hearings before the Committee on Foreign Affairs, House of Representatives, $81^{\text {st }}$ Congress, $2^{\text {nd }}$ Session. US Government Publication Office.

United States Government. (1945), A postwar foreign trade program for United States agriculture. Washington: USDA/Interbureau Committee on Post-War Programs.

United States Government. (1945). Proposals for expansion of world trade and employment. Washington: US Department of State, Publication 2411.

United States Government. (1946). Suggested Charter for an International Trade Organization of the United Nations. Washington, US Department of State, Publication 2598.

United States Government. (1946). Basic principles in establishment of International Trade Organization. Washington: US Department of State Bulletin, October 27, pp. 757-760.

United States Government. (1948). The United States reciprocal trade-agreements program and the proposed International Trade Organization. Washington: US Department of State, Bulletin, March 21, pp. 367-373.

Zeiler, T. W. (1992). American trade and power in the 1960s. New York: Columbia University Press.

\section{Notes}

Note 1. The elements of the ITO may be traced to US lend-lease agreements, wartime discussions on possible economic cooperation between nations, the Bretton Woods conference and the creation of FAO, as well as the US-UK loan agreement. ITO preparation included four conferences: London Conference (October-November 1946), where the joint US-UK ITO proposal (Suggested Charter for an International Trade Organization of the United 
Nations) was presented; conferences in Lake Success (January-February 1947) and Geneva (April-August 1947), where amendments, exemptions and reservations to the US-UK draft were made and where several commercial policy provisions of the draft were put into application; and the UN Conference on Trade and Employment in Havana (November 1947-March 1948), which resulted in the Charter for an International Trade Organization (Havana Charter). Signed by 53 countries on March 24, 1948, it was to be submitted to national parliaments for ratification; following this ITO would have come into existence. See United States Government (1946) and United Nations Conference on Trade and Employment (1948).

Note 2. We view the de-legitimisation of ideas as an entrepreneurial process of "creative destruction", whereby entrepreneur introduces innovations (material or ideational) by displacing the existing ideas or economic and political structures (Schumpeter, 1934). Hence framing is conceptualized as entrepreneurship.

Note 3. The frame may be inferred from United States Government (1945).

Note 4. Due to collective nature of policymaking the entrepreneurial construction will also be collective, relying on inputs from different actors and sources. The possibility of collective entrepreneurship was acknowledged by Schumpeter in Business Cycles (1939).

Note 5. Indeed, codification and comprehensiveness as modes of law making are suitable for ordering existing but scattered rules, rather than for regulating yet unsettled relations or governing previously unchartered areas. The GATT in this sense relied less on these two methods, allowing countries to join certain agreements in new regulatory areas on voluntary basis (plurilateral liberalization) and limiting its early Rounds to selected issues (tariffs reduction). The greater reliance on comprehensiveness during Tokyo and especially Uruguay Rounds, with attempts to embrace a greater number of issues (services, standards, technical barriers, agriculture) in a single undertaking, ceteris paribus, made talks more prolonged and organizationally challenging. Likewise the GATT did not attempt, as opposed to the ITO, to fix and impose detailed rules on ex ante basis. Rather, it allowed countries to negotiate details in the course of actual Rounds (and make certain exemptions, permit adjustment periods, differential liberalization pace) within the framework of general rules. Thus, in the ITO, international trade lawmaking should have been more ingenuous, being guided more by appropriateness and flexibility logic, rather than by strict conformity to normative economic rules, and taking into account already existing domestic laws. It may be objected that this lax attitude to domestic agricultural support policies led to subsequent problems with agriculture in the GATT. We show in the next paragraph that agricultural exemptionalism and associated disarray in international agricultural policy followed from the reluctance of US negotiators in the DoS to utilize workable templates for agricultural regulation.

Note 6. In the Preparatory Committee, the economists from the International Chamber of Commerce (representing business interests) advocated, rather unsuccessfully, the removal of the employment and planning policies from the ITO agenda. Also, after the Havana Charter came back to the US, with all anti-free trade amendments being made, several economists advocated against its ratification by the US Congress, particularly L. von Mises, M. A. Heilperin and G. Garrett. They were joined by business economists and economic observers such as P. Cortney, comparing ITO ratification to "economic Munich" and castigating Havana Charter supporters as Keynesian zealots, ignorants or 'do-gooders'. See Garrett (1947), Cortney (1949), United Nations (1947).

Note 7. Indeed a careful reading of the anti-cartel provisions reveals that US businesses were not required to do more than other countries to promote competition, or more than the US domestic anti-trust legislation prescribed. Specifically, for commercial and financial services in which the USA had a competitive advantage, the Havana Charter was particularly lax - restrictive practices there were not explicitly prohibited (Article 53). 